\title{
Synthesis and Electrochemical Properties of New Main Chain Type Polyquinones Constituted of Thiophene-F used Benzoquinone and Transformation of the Polymers to a Dicyanoquinonediimine Type Polymer
}

\author{
Kouichi SHIRAISHI and Takakazu YAMAMOTO ${ }^{\dagger}$ \\ Chemical Resources Laboratory, Tokyo Institute of Technology, 4259 \\ Nagatsuta, Midori-ku, Yokohama 226-8503, Japan
}

(Received April 22, 2002; Accepted August 11, 2002)

\begin{abstract}
New main chain type polyquinones, poly(3,7-dialkylbenzo[1,2- $\left.b: 4,5-b^{\prime}\right]$ dithiophene-4,8-dione-2,6diyl), $\mathrm{P}\left(2,6-\mathrm{Th}_{2} \mathrm{~Bq}(\mathrm{diR})\right)(\mathrm{R}=\mathrm{hexyl}(\mathrm{Hex})$; octyl(Oct); dodecyl(Dod)), and poly(benzo[1,2-c:4,5-c' $]$ dithiophene-4,8dione-1,3-diyl), $\mathrm{P}\left(1,3-\mathrm{Th}_{2} \mathrm{~Bq}\right)$, were prepared by organometallic polycondensation. $\mathrm{P}\left(2,6-\mathrm{Th}_{2} \mathrm{~Bq}(\mathrm{diR})\right)$ was soluble in organic solvents such as chloroform and dichloromethane. $\mathrm{P}\left(1,3-\mathrm{Th}_{2} \mathrm{~Bq}\right)$ is soluble in $\mathrm{CF}_{3} \mathrm{COOH}$, $\mathrm{NMP}$, and $\mathrm{DMI}(1,3-$ dimethyl-2-imidazolidione). $\mathrm{P}\left(2,6-\mathrm{Th}_{2} \mathrm{~Bq}(\right.$ diHex $\left.)\right)$ received electrochemical two step reduction with peak reduction potentials $\left(E_{\mathrm{pc}}\right)$ of $-1.18 \mathrm{~V}$ and $-1.84 \mathrm{~V} v s . \mathrm{Ag}^{+} / \mathrm{Ag}$, respectively. This electrochemical reduction corresponds to Wurster type reduction characteristic of quinones. $\mathrm{P}\left(1,3-\mathrm{Th}_{2} \mathrm{~Bq}\right)$ was also electrochemically active and its reduction took place at $E_{\mathrm{pc}}=-1.50 \mathrm{~V}$ and $-1.74 \mathrm{~V} v s . \mathrm{Ag}^{+} / \mathrm{Ag}$. The film of $\mathrm{P}\left(1,3-\mathrm{Th}_{2} \mathrm{~Bq}\right)$ changed its color from brown to blue (electrochromism) on the electrochemical reduction. Powder XRD patterns of $\mathrm{P}\left(2,6-\mathrm{Th}_{2} \mathrm{~Bq}(\mathrm{diR})\right)$ s indicated that they assumed an ordered structure; they showed an XRD peak in a low angle region $\left(2 \theta(\mathrm{Cu}-K \alpha)<7^{\circ}\right)$. The $d$-value of the peak increased linearly with increase in the number of the carbon of the R groups, suggesting that the $d$-value corresponded to a distance between the polymer main chains separated by the $\mathrm{R}$ groups and $\mathrm{P}\left(2,6-\mathrm{Th}_{2} \mathrm{~Bq}(\mathrm{diR})\right)$ took a stacked structure in the solid. The quinone unit of $\mathrm{P}\left(2,6-\mathrm{Th}_{2} \mathrm{~Bq}(\mathrm{diR})\right) \mathrm{s}$ was transformed to a strong electron withdrawing dicyanoquinonediimine (DCQNI) unit by reaction with bis(trimethylsilylcarbodiimide) (TMS-N $=\mathrm{C}=\mathrm{N}-\mathrm{TMS}$ ); a high degree of transformation was observed by elemental analysis. A cast film of the obtained polymer underwent the electrochemical reduction with the first $E_{\mathrm{pc}}{ }^{1}$ at a very high potential of $-0.56 \mathrm{~V} v \mathrm{~s}$. $\mathrm{Ag}^{+} / \mathrm{Ag}$, reflecting the high electron-withdrawing properties of the DCNQI unit.

KEY WORDS $\pi$-Conjugated Polymer/ Organometallic Polycondensation / Thiophene-Fused Benzoquinone / Electrochemical Response / Thiophene-Fused Dicyanoquinonediimine (DCNQI) /
\end{abstract}

There has been current interest in the synthesis of novel $\pi$-conjugated polymers as interesting and useful optical and electronic materials. ${ }^{1}$ Among the $\pi$ conjugated polymers, those constituted of redox active recurring units have attracted attention due to their interesting electrochemical behavior. Quinones are known as typical redox active compounds and a number of papers have been published about redox behaviors of quinone and its derivatives. ${ }^{2}$ In spite of their attractive properties, examples of polymers consisting of the quinone units are still limited., Peover and co-workers reported the preparation of meta-bonded poly(hydroquinone) and its electrochemical responses. ${ }^{3 a}$ Arai and co-workers reported electrochemical synthesis of poly(mercapto- $p$-benzoquinone) and poly(mercapto- $p$-hydroquinone). ${ }^{3 \mathrm{~b}}$ However, in these cases, the bonding modes of the monomeric units in the polymer chains are not controlled and their chemical properties have not been revealed well.

Previously, we reported preparation of polyanthraquinones and poly( $p$-benzoquinone) having

${ }^{\dagger}$ To whom correspondence should be addressed. quinone units in the main-chain via organometallic polycondensations. ${ }^{4}$ The obtained polyquinones had well-defined structures and polyanthraquinones were soluble in organic solvents. Hodge and coworkers also reported preparation of another main-chain-type polyanthraquinone via similar organometallic polycondensation. $^{5}$ The main-chain-type polyquinones are redox active and their usefulness as an electron carrying layer in organic electric devices (e.g., EL device and organic transistor) is expected. In order to expand the scope of the main-chain-type polyquinones, we have prepared the following new two types of polyquinones, both being constituted of the thiophene-fused benzoquinones. $\pi$-Conjugated polymers composed of thiophene units show interesting chemical and physical properties including self-assembling property, and various thiophene-based $\pi$-conjugated polymers have been prepared. ${ }^{1}$ Some of the polymers are now industrially used. Electronic and optical data of $\mathrm{P}\left(2,6-\mathrm{Th}_{2} \mathrm{~Bq}(\mathrm{diR})\right)$ and $\mathrm{P}\left(1,3-\mathrm{Th}_{2} \mathrm{~Bq}\right)$ are expected to give bases for better understanding of the thiophene-based polymers. 


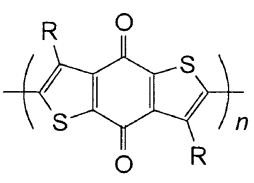

$\mathrm{P}\left(2,6-\mathrm{Th}_{2} \mathrm{~Bq}(\mathrm{diR})\right)$
$\mathrm{P}\left(1,3-\mathrm{Th}_{2} \mathrm{~Bq}\right)$

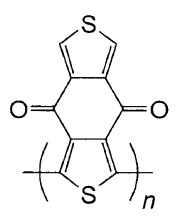

Herein we report preparation of the above shown polymers and their electrochemical responses. The benzoquinone unit in $\mathrm{P}\left(2,6-\mathrm{Th}_{2} \mathrm{~Bq}(\mathrm{diR})\right) \mathrm{s}$ can be converted into a highly electron accepting dicyanoquinonediimine (DCNQI) ${ }^{6}$ unit and electrochemical properties of the DCNQI polymer will also be reported.

\section{EXPERIMENTAL}

\section{Measurements}

IR spectra were recorded on a JASCO IR-810 spectrometer. NMR spectra were taken using a JEOL EX400 or EX-90 spectrometer. X-Ray diffraction patterns were recorded on a Philips PS-1051 instrument. Microanalyses of $\mathrm{C}, \mathrm{H}$, and $\mathrm{N}$ were carried out with a Leco CHNS-932 or a Yanaco CHN CORDER MT-5. Analyses of halogen and sulfur were carried out on a Leco CHNS-932 (sulfur) or a Yanaco YS-10 (halogen). GPC analysis was carried out with a Shimadzu C-R7A equipped with an $\mathrm{LC} 9 \mathrm{~A}$ column using a $\mathrm{CHCl}_{3}$ solution as an eluent or Tosoh HLC-8020 gel permeation chromatograph (polystyrene standards; eluent $=$ DMF containing $0.01 \mathrm{M}$ of LiBr). UV-vis spectra were measured with a Shimadzu UV-3100PC spectrometer. Cyclic voltammograms were obtained with a Hokuto Denko HA-501 galvano/potentiostat and a Hokuto Denko HB104 function generator using an $\mathrm{CH}_{3} \mathrm{CN}$ solution of $\left[\mathrm{NBu}_{4}\right] \mathrm{PF}_{6}(0.10 \mathrm{M})$ under nitrogen. Density of the polymer samples were measured by sink and float tests using aqueous solutions of $\mathrm{ZnCl}_{2}$.

Synthesis of 2,6-Dibromo-3,7-dihexyl-4,8-dihydrobenzo[1,2-b:4,5-b']dithiophene-4,8-dione (2,6-Dibromo$T h_{2} B q($ diHex))

This monomer was prepared by modifying a literature method. ${ }^{7}$ A typical procedure is as follows. A mixture of 3-(dimethylaminocarbonyl)-4-hexyl-2,5dibromothiophene $(1.2 \mathrm{~g}, 3.3 \mathrm{mmol})$ with $n$-BuLi ( $3.3 \mathrm{mmol}$ ) in dry ether was stirred for $1 \mathrm{~h}$ at $-78^{\circ} \mathrm{C}$ and continuously for $12 \mathrm{~h}$ at room temperature. The reaction mixture was poured into $1 \mathrm{M} \mathrm{HCl}(\mathrm{aq})$ and extracted with ether for three times. Purification by column chromatography on $\mathrm{SiO}_{2}$ with chloroform/hexane (1/1) gave a yellow solid. After recrystalization from hexane, yellow needles of 2,6-dibromo-3,7-dihexyl-4,8- dihydrobenzo[1,2- $\left.b: 4,5-b^{\prime}\right]$ dithiophene-4,8-dione, 2,6dibromo- $\mathrm{Th}_{2} \mathrm{~Bq}$ (diHex), were obtained. Yield $33 \%$. $\mathrm{Mp} 132{ }^{\circ} \mathrm{C} .{ }^{1} \mathrm{H}$ NMR $\left(\mathrm{CDCl}_{3}, 400 \mathrm{MHz}\right): \delta 0.89(\mathrm{t}$, $6 \mathrm{H}), 1.30-1.55(\mathrm{~m}, 16 \mathrm{H}), 2.96(\mathrm{t}, 4 \mathrm{H})$. Anal. Calcd. for $\left(\mathrm{C}_{22} \mathrm{H}_{26} \mathrm{Br}_{2} \mathrm{O}_{2} \mathrm{~S}_{2}\right): \mathrm{C}, 48.8 ; \mathrm{H}, 4.8 ; \mathrm{Br}, 29.1 ; \mathrm{S}$, 11.4\%. Found: C, 48.5; H, 4.9; Br, 29.4; S, 11.8\%.

\section{3,7-Dihexyl-4, 8-dihydrobenzo[1,2-b:4,5- $\left.b^{\prime}\right]$ dithiophe- ne-4,8-dione, $\mathrm{Th}_{2} \mathrm{~Bq}$ (diHex)}

This monomeric model compound for the repeating unit, was prepared in an analogous way from 3-(dimethylaminocarbonyl)-4-hexylthiophene. Yield $34 \%$. Mp $84{ }^{\circ} \mathrm{C} .{ }^{1} \mathrm{H}$ NMR $\left(\mathrm{CDCl}_{3}, 400 \mathrm{MHz}\right): \delta 1.1(\mathrm{t}$, $6 \mathrm{H}), 1.30-1.89(\mathrm{~m}, 16 \mathrm{H}), 3.30(\mathrm{t}, 4 \mathrm{H}), 7.30(\mathrm{~s}, 2 \mathrm{H})$. Anal. Calcd. for $\left(\mathrm{C}_{22} \mathrm{H}_{28} \mathrm{O}_{2} \mathrm{~S}_{2}\right): \mathrm{C}, 68.0 ; \mathrm{H}, 7.3 ; \mathrm{S}$, $16.5 \%$. Found: C, 67.6; H, 7.0; S, 16.3\%.

Other dibromo monomers, 2,6-dibromo- $\mathrm{Th}_{2} \mathrm{~Bq}$ $($ diOct $)($ Yield $=48 \%)$ and 2,6-dibromo- $\mathrm{Th}_{2} \mathrm{~Bq}(\mathrm{diDod})$ (Yield $=26 \%$ ) were prepared similarly. 2,6-Dibromo$\mathrm{Th}_{2} \mathrm{~Bq}$ (diOct): $\mathrm{Mp} 117^{\circ} \mathrm{C} .{ }^{1} \mathrm{H}$ NMR $\left(\mathrm{CDCl}_{3}, 400\right.$ $\mathrm{MHz}): \delta 0.89(\mathrm{t}, 6 \mathrm{H}), 1.30-1.55(\mathrm{~m}, 24 \mathrm{H}), 2.96(\mathrm{t}$, $4 \mathrm{H})$. Anal. Calcd. for $\left(\mathrm{C}_{26} \mathrm{H}_{34} \mathrm{Br}_{2} \mathrm{O}_{2} \mathrm{~S}_{2}\right)$ : C, 51.8; $\mathrm{H}, 5.7 ; \mathrm{Br}, 26.5 ; \mathrm{S}, 10.6 \%$. Found: $\mathrm{C}, 52.2 ; \mathrm{H}, 5.5$; $\mathrm{Br}, 26.9$; S, 10.8\%. 2,6-Dibromo- $\mathrm{Th}_{2} \mathrm{~Bq}$ (diDod): $\mathrm{Mp}$ $100{ }^{\circ} \mathrm{C} .{ }^{1} \mathrm{H} \mathrm{NMR}\left(\mathrm{CDCl}_{3}, 400 \mathrm{MHz}\right): \delta 0.88(\mathrm{t}, 6 \mathrm{H})$, 1.26-1.53 (m, $40 \mathrm{H}), 2.95(\mathrm{t}, 4 \mathrm{H})$. Anal. Calcd. for $\left(\mathrm{C}_{34} \mathrm{H}_{50} \mathrm{Br}_{2} \mathrm{O}_{2} \mathrm{~S}_{2}\right)$ : C, 57.1; H, 7.1; Br, 22.4; S, 9.0\%. Found: $\mathrm{C}, 57.2 ; \mathrm{H}, 7.0 ; \mathrm{Br}, 22.7 ; \mathrm{S}, 8.9 \%$.

Synthesis of 1,3-Dibromo-4,8-dihydrobenzo[1,2-c:4,5$c^{\prime}$ ]dithiophene-4,8-dione (1,3-dihydro- $T h_{2} B q$ )

This monomer was prepared by modifying a literature method. ${ }^{8}$ To a solution of $\mathrm{AlCl}_{3}(0.53 \mathrm{~g}$, $4.0 \mathrm{mmol})$ and $\mathrm{CH}_{3} \mathrm{NO}_{2}(0.24 \mathrm{~g}, 4.0 \mathrm{mmol})$ in dry 1,2-dichroloethene $(5 \mathrm{~mL})$ was added thiophene-3,4dicarboxylic acid chloride $(0.42 \mathrm{~g}, 2.0 \mathrm{mmol})$ in dry 1,2-dichloroethene $(5 \mathrm{~mL})$. The resulting solution was stirred for $15 \mathrm{~min}$, and then 2,5-dibromothiophene $(0.80 \mathrm{~g}, 3.0 \mathrm{mmol})$ was added. The red-brown mixture was stirred for $48 \mathrm{~h}$ at $60^{\circ} \mathrm{C}$. The reaction mixture was poured into $6 \mathrm{M} \mathrm{HCl}(\mathrm{aq})$ and extracted with chloroform for three times. The organic layer were washed with saturated $\mathrm{NaHCO}_{3}$ (aq) and dried with $\mathrm{MgSO}_{4}$. Purification from column chromatography on $\mathrm{Al}_{2} \mathrm{O}_{3}$ with chloroform/hexane (1/1) gave a pale yellow solid. After recrystalization from chloroform/hexane, a pale yellow solid of 1,3-dibromo-4,8-dihydrobenzo [1,2-c:4,5$c^{\prime}$ ]dithiophene-4,8-dione, 1,3-dibromo- $\mathrm{Th}_{2} \mathrm{~Bq}$, was obtained. Yield $16 \% .{ }^{1} \mathrm{H}$ NMR $\left(\mathrm{CDCl}_{3}, 400 \mathrm{MHz}\right): \delta$ 8.05 (s, $2 \mathrm{H})$. Anal. Calcd. for $\left(\mathrm{C}_{10} \mathrm{H}_{2} \mathrm{Br}_{2} \mathrm{O}_{2} \mathrm{~S}_{2}\right): \mathrm{C}$, $31.8 ; \mathrm{H}, 0.5 ; \mathrm{Br}, 42.3 ; \mathrm{S}, 17.0 \%$. Found: $\mathrm{C}, 31.7 ; \mathrm{H}$, $0.5 ; \mathrm{Br}, 42.4 ; \mathrm{S}, 16.9 \%$. 


\section{Ni(0) Promoted Dehalogenative Polycondensation}

Preparation of the polymer was carried out by using a zerovalent nickel complex. ${ }^{9}$ A typical procedure is as follows. To a dark purple solution containing bis $(1,5-$ cyclooctadiene)nickel $(0), \mathrm{Ni}(\operatorname{cod})_{2},(0.30 \mathrm{~g}, 1.1 \mathrm{mmol})$ and 2,2' -bipyridyl, 2,2'-bpy, $(0.17 \mathrm{~g}, 1.1 \mathrm{mmol})$ in dry DMF $(15 \mathrm{~mL})$ was added 2,6-dibromo- $\mathrm{Th}_{2} \mathrm{~Bq}$ (diHex) $(0.38 \mathrm{~g}, 0.70 \mathrm{mmol})$. The dark brown mixture was stirred for $48 \mathrm{~h}$ at $60^{\circ} \mathrm{C}$. The reaction mixture was poured into $1 \mathrm{M} \mathrm{HCl}(\mathrm{aq})$, and the obtained brown powder was washed with $1 \mathrm{M} \mathrm{HCl}(\mathrm{aq})$, an aqueous solution of disodium EDTA for three times, distilled $\mathrm{H}_{2} \mathrm{O}$, and $\mathrm{MeOH}$. Reprecipitation from a chloroform solution to hexane gave a light brown powder of poly(3,7-dihexyl4,8-dihydrobenzo[1,2- $\left.b: 4,5-b^{\prime}\right]$ dithiophene-4,8-dione2,6-diyl), $\mathrm{P}\left(2,6-\mathrm{Th}_{2} \mathrm{~Bq}\right.$ (diHex)). Yield 98\%. ${ }^{1} \mathrm{H}$ NMR $\left(\mathrm{CDCl}_{3}, 400 \mathrm{MHz}\right): \delta 0.89-1.70\left(22 \mathrm{H},-\mathrm{C}_{5} \mathrm{H}_{11}\right.$ of the hexyl group), 2.8-3.1 (4 $\mathrm{H}$, methylene proton). Anal. Calcd. for $\left(\mathrm{C}_{22} \mathrm{H}_{26} \mathrm{O}_{2} \mathrm{~S}_{2} \cdot 0.5 \mathrm{H}_{2} \mathrm{O}\right)_{n}$ : C, 66.8; $\mathrm{H}, 6.9$; S, $16.2 \%$. Found: C, 66.5; H, 6.7; Br, 0.0; S, 16.5\%. Other $\mathrm{P}\left(2,6-\mathrm{Th}_{2} \mathrm{~Bq}(\mathrm{diR})\right) \mathrm{s}$ were prepared similarly. $\mathrm{P}\left(2,6-\mathrm{Th}_{2} \mathrm{~Bq}\right)(\mathrm{R}=\mathrm{H})$ : Yield $=79 \% . \quad{ }^{1} \mathrm{H}$ NMR (DMSO- $d_{6}, 400 \mathrm{MHz}$ ): $\delta 7.8$ (2H of 3,7-positions). Anal. Calcd. for $\mathrm{Br}\left(\mathrm{C}_{10} \mathrm{H}_{2} \mathrm{O}_{2} \mathrm{~S}_{2} \cdot 0.6 \mathrm{H}_{2} \mathrm{O}\right)_{3} \mathrm{Br}$ : C, 42.5; H, 1.1; S, 22.7; Br, 18.9\%. Found: $\mathrm{C}, 42.5$; $\mathrm{H}$, $1.2 ; \mathrm{S}, 22.5 ; \mathrm{Br}, 18.9 \%$. $\mathrm{P}\left(2,6-\mathrm{Th}_{2} \mathrm{~Bq}(\right.$ diOct $\left.)\right)(\mathrm{R}=$ $\left.n-\mathrm{C}_{8} \mathrm{H}_{17}\right)$ : Yield $=89 \% .{ }^{1} \mathrm{H} \mathrm{NMR}\left(\mathrm{CDCl}_{3}, 400 \mathrm{MHz}\right)$ : $\delta{ }^{1} \mathrm{H}$ NMR $\left(\mathrm{CDCl}_{3}, 400 \mathrm{MHz}\right): \delta 0.89-1.70(30 \mathrm{H}$, $-\mathrm{C}_{7} \mathrm{H}_{15}$ of octyl group), 2.8-3.1 (4 H, methylene proton). Anal. Calcd. for $\mathrm{Br}\left(\mathrm{C}_{26} \mathrm{H}_{34} \mathrm{O}_{2} \mathrm{~S}_{2}\right){ }_{3} \mathrm{Br}$ : C, 63.0; H, 6.9; S, 12.9; Br, 10.7\%. Found: C, 62.9; $\mathrm{H}, 7.4 ; \mathrm{S}, 12.1 ; \mathrm{Br}, 10.0 \%$. $\mathrm{P}\left(2,6-\mathrm{Th}_{2} \mathrm{~Bq}(\right.$ diDod $\left.)\right)$ $\left(\mathrm{R}=n-\mathrm{C}_{12} \mathrm{H}_{25}\right):$ Yield $=88 \% . \quad \delta^{1} \mathrm{H}$ NMR $\left(\mathrm{CDCl}_{3}\right.$, $400 \mathrm{MHz}): \delta 0.89-1.70\left(46 \mathrm{H},-\mathrm{C}_{11} \mathrm{H}_{23}\right.$ of dodecyl group), 2.8-3.1 (4H of methylene proton). Anal. Calcd. for $\mathrm{Br}\left(\mathrm{C}_{34} \mathrm{H}_{50} \mathrm{O}_{2} \mathrm{~S}_{2}\right)_{3} \mathrm{Br}: \mathrm{C}, 67.2 ; \mathrm{H}, 8.3 ; \mathrm{S}$, $10.6 ; \mathrm{Br}, 8.8 \%$. Found: $\mathrm{C}, 67.3 ; \mathrm{H}, 8.0 ; \mathrm{S}, 11.1 ; \mathrm{Br}$, $8.0 \%$.

Synthesis of $\mathrm{P}\left(1,3-\mathrm{Th}_{2} \mathrm{~Bq}\right)$ was carried out analogously to yield a light brown powder. Yield $88 \% .{ }^{1} \mathrm{H}$ NMR $\left(\mathrm{CF}_{3} \mathrm{CO}_{2} \mathrm{D}, 400 \mathrm{MHz}\right): \delta 8.55(\mathrm{~s}, 2 \mathrm{H})$. Anal. Calcd. for $\left(\mathrm{C}_{10} \mathrm{H}_{2} \mathrm{O}_{2} \mathrm{~S}_{2}\right)_{n}$ : C, 54.5; H, 1.8; S, 29.1\%. Found: $\mathrm{C}, 54.2 ; \mathrm{H}, 1.7 ; \mathrm{Br}, 0.0 ; \mathrm{S}, 26.6 \%$.

\section{Transformation of $P\left(2,6-B_{q} T_{2}(d i R)\right)$ to the Dicyano-} quinonediimine Polymer

To a solution of $\mathrm{P}\left(2,6-\mathrm{Th}_{2} \mathrm{~Bq}(\mathrm{diHex})\right)(106 \mathrm{mg})$ in dry toluene $(10 \mathrm{~mL})$ was added a toluene solutions of $1 \mathrm{M} \mathrm{TiCl}_{4}(0.55 \mathrm{mmol})$, and the mixture was stirred for $24 \mathrm{~h}$ at $90{ }^{\circ} \mathrm{C}$, similar to cases applied for low molecular weight quinones. ${ }^{10}$ The resulting mixture was poured into $1 \mathrm{M} \mathrm{HCl}(\mathrm{aq})$ and the product was extracted with chloroform. The organic layer was con- centrated and poured into an excess amount of hexane to yield a black powder of the polymer containing DCNQI units. Yield, $60 \mathrm{mg}$. Anal. Calcd. for $\left\{\left(\mathrm{C}_{22} \mathrm{H}_{26} \mathrm{O}_{2} \mathrm{~S}_{2}\right)_{0.1}\left(\mathrm{C}_{24} \mathrm{H}_{26} \mathrm{~N}_{4} \mathrm{~S}_{2}\right)_{0.9} \cdot \mathrm{H}_{2} \mathrm{O}\right\}: \mathrm{C}, 63.8 ; \mathrm{H}$, 6.3 ; N, 11.3; S, 14.3\%. Found: C, 64.0; H, 6.3; N, $11.4 ; \mathrm{S}, 13.7 \%$.

\section{RESULTS AND DISCUSSION}

\section{Preparation}

The monomer and its hydrogen terminated compound, $\mathrm{Th}_{2} \mathrm{~Bq}$ (diHex) (with $\mathrm{H}$ at the 2- and 6-positions instead of Br: monomeric model compound for the polymer), were prepared from the corresponding thiophene derivatives by modifying the previously reported method (Scheme 1). ${ }^{6}$

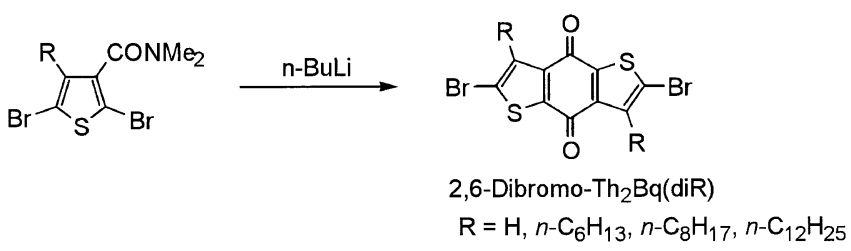

Scheme 1. Synthesis of monomer. The model compound without $\mathrm{Br}, \mathrm{Th}_{2} \mathrm{~Bq}(\mathrm{diHex})$, was also prepared analogously.

1,3-Dibromo-benzo[1,2-c:4,5-c' $]$ dithiophene-4,8-dione (1,3-dibromo- $\left.\mathrm{Th}_{2} \mathrm{~Bq}\right)$ was prepared by FriedelCrafts reaction with 3,4-thiophene carboxylic acid chloride and 2,5-dibromothiophene in the presence of $\mathrm{AlCl}_{3}$ (Scheme 2). ${ }^{8}$

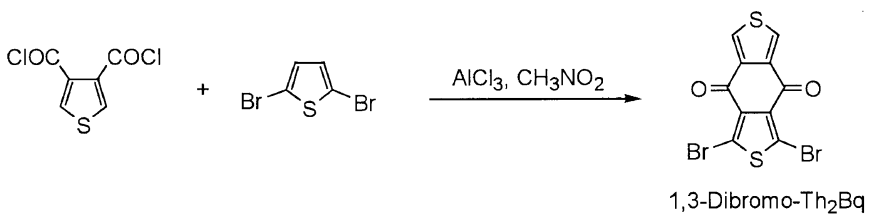

Scheme 2. Synthesis of 1,3-dibromo- $\mathrm{Th}_{2} \mathrm{~Bq}$.

The previously reported organometallic polycondensation $^{9}$ using the zero valent nickel comlex (a mixture of $\mathrm{Ni}(\operatorname{cod})_{2}$ and bpy) was applicable to the present cases, and the polycondensation in DMF at $60^{\circ} \mathrm{C}$ for $48 \mathrm{~h}$ (Scheme 3) gave the corresponding polymers in good yield (79-98\%).

Results of the organometallic polycondensation are summarized in Table I.

$\mathrm{P}\left(2,6-\mathrm{Th}_{2} \mathrm{~Bq}\right)$ was insoluble in organic or aqueous solvents so far tested, however, $\mathrm{P}\left(2,6-\mathrm{Th}_{2} \mathrm{~Bq}(\mathrm{diR})\right)$ containing long alkyl chains at the 3,7-positions were soluble in chloroform, dichloromethane, and toluene. $\mathrm{P}\left(1,3-\mathrm{Th}_{2} \mathrm{~Bq}\right)$ was also soluble in organic solvents such as $\mathrm{CF}_{3} \mathrm{COOH}$, NMP ( $\mathrm{N}$-methyl-2-pyrrolidinone), and DMI (1,3-dimethyl-2-imidazolidinone). GPC 


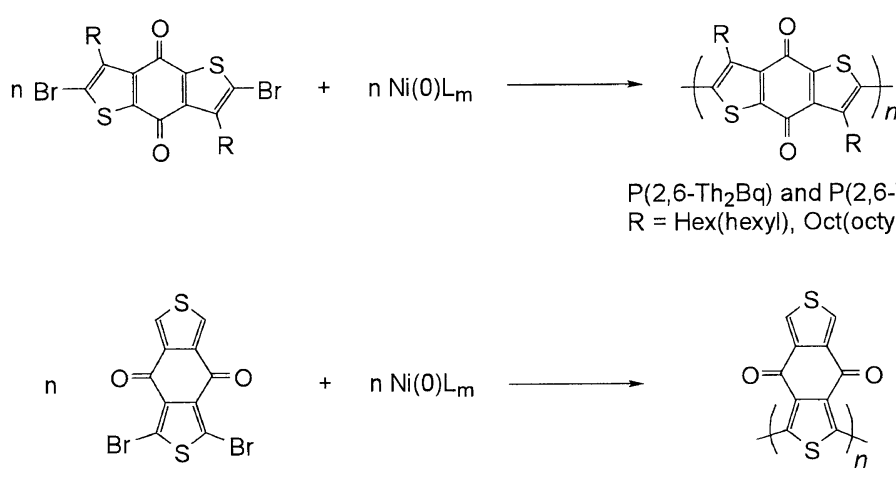

$\mathrm{P}\left(1,3-\mathrm{Th}_{2} \mathrm{~Bq}\right)$

$\mathrm{Ni}(0) L_{m}$ : a mixture of bis(cyclooctadiene)nickel $(0)$,

$\mathrm{Ni}(\operatorname{cod})_{2}$, and 2,2'-bipyridyl, bpy.

Scheme 3. Synthesis of polyquinones.

Table I. Results of the polymerization

\begin{tabular}{|c|c|c|c|c|c|}
\hline run & Compound & $\frac{\text { Yield }}{\%}$ & Color & $M_{\mathrm{n}} \times 10^{-}$ & $M_{\mathrm{w}} / M_{\mathrm{n}}$ \\
\hline 1 & $\mathrm{P}\left(2,6-\mathrm{Th}_{2} \mathrm{~Bq}\right)$ & 79 & dark brown & $-\mathrm{b}$ & - \\
\hline 2 & $\mathrm{P}\left(2,6-\mathrm{Th}_{2} \mathrm{~Bq}(\mathrm{diHex})\right)$ & 98 & light brown & $3.5^{\mathrm{c}}$ & 1.34 \\
\hline 3 & $\mathrm{P}\left(2,6-\mathrm{Th}_{2} \mathrm{~Bq}(\mathrm{diOct})\right)$ & 89 & light brown & $2.5^{\mathrm{c}}$ & 1.20 \\
\hline 4 & $\mathrm{P}\left(2,6-\mathrm{Th}_{2} \mathrm{~Bq}(\mathrm{diDod})\right)$ & 91 & light brown & $2.0^{\mathrm{c}}$ & 1.25 \\
\hline 5 & $\mathrm{P}\left(1,3-\mathrm{Th}_{2} \mathrm{~Bq}\right)$ & 88 & light brown & $6.5^{\mathrm{d}}$ & 1.31 \\
\hline
\end{tabular}

analysis indicated that $\mathrm{P}\left(2,6-\mathrm{Th}_{2} \mathrm{~Bq}(\mathrm{diHex})\right)$ (eluent $=$ chloroform; $v s$. polystyrene standards) and DMF soluble part of $\mathrm{P}\left(1,3-\mathrm{Th}_{2} \mathrm{~Bq}\right.$ ) (eluent $=\mathrm{DMF}$ $v s$. polystyrene standards) had number average molecular weights, $M_{\mathrm{n}}$, of 3500 and 6500 with weight average molecular weights, $M_{\mathrm{w}}$, of 4700 and 8500 , respectively. $\quad \mathrm{P}\left(2,6-\mathrm{Th}_{2} \mathrm{~Bq}(\mathrm{diR})\right)$ having a longer alkyl side chain, $-\mathrm{C}_{8} \mathrm{H}_{17}$ or $-\mathrm{C}_{12} \mathrm{H}_{25}$, showed lower molecular weight as shown in Table I. The dihexyl monomer had sufficient solubility in the polymerization solvent, however, the dioctyl and didodecyl monomers had poor solubility in the solvent, and this may be the reason for the lower molecular weights of $\mathrm{P}\left(2,6-\mathrm{Th}_{2} \mathrm{~Bq}(\mathrm{diOct})\right)$ and $\mathrm{P}\left(2,6-\mathrm{Th}_{2} \mathrm{~Bq}(\mathrm{diDod})\right)$. The IR spectra of $\mathrm{P}\left(2,6-\mathrm{Th}_{2} \mathrm{~Bq}(\mathrm{diHex})\right)$ and $\mathrm{P}\left(1,3-\mathrm{Th}_{2} \mathrm{~Bq}\right)$ resembled those of their corresponding monomers, except for disappearance of a $v(\mathrm{C}-\mathrm{Br})$ absorption band at about $1100 \mathrm{~cm}^{-1} \cdot 11$ They showed absorption peak characteristic of carbonyl groups at about $1650 \mathrm{~cm}^{-1}$, indicating that the $\mathrm{C}=\mathrm{O}$ group remained intact, similar to cases of the previously reported synthesis of polyquinones. ${ }^{4}$

Figure 1 exhibits the ${ }^{1} \mathrm{H}$ NMR spectrum of $\mathrm{P}(2,6-$ $\mathrm{Th}_{2} \mathrm{~Bq}(\mathrm{diHex})$ ) in $\mathrm{CDCl}_{3}$ at room temperature; the peak area ratios agree with the structure of the polymer. Splitting of the $\alpha-\mathrm{CH}_{2}$ signal attached at the aromatic ring into two peaks at $\delta 2.8$ and 3.0 is considered to

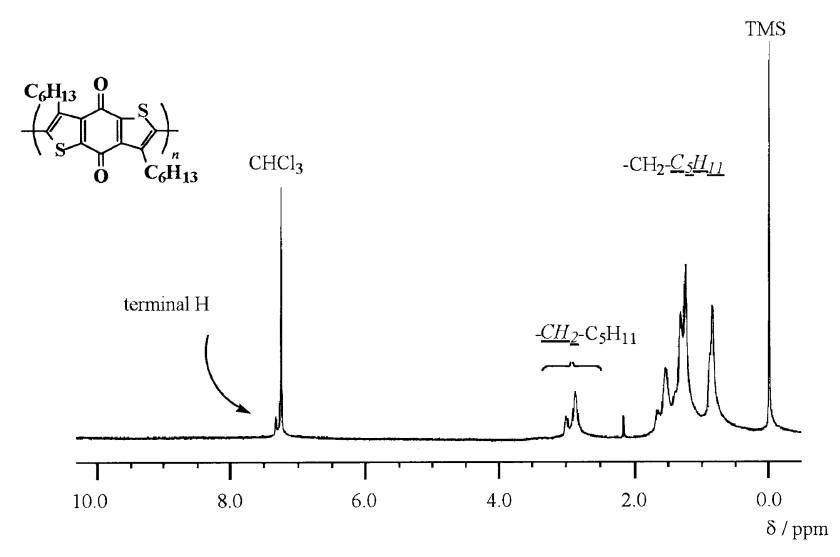

Figure 1. ${ }^{1} \mathrm{H}$ NMR spectrum of $\mathrm{P}\left(2,6-\mathrm{Th}_{2} \mathrm{~Bq}(\mathrm{diHex})\right)$ in $\mathrm{CDCl}_{3}$.

be due to the presence of s-cis and s-trans rotamers concerning the bond connecting the monomeric units and/or due to the terminal groups. Measurement of the ${ }^{1} \mathrm{H}$ NMR spectrum at $50^{\circ} \mathrm{C}$ showed essentially the same splitting of the $\alpha-\mathrm{CH}_{2}$ signal, suggesting that the weaker peak at $\delta 3.0$ originate from the terminal unit. However, if this is the case, the area of the peak at $\delta 3.0$ suggests that not only the $\alpha-\mathrm{CH}_{2}$ group in the terminal unit but also that in the penultimate unit contribute to the peak at $\delta 3.0$. Since $\mathrm{P}\left(2,6-\mathrm{Th}_{2} \mathrm{~Bq}(\mathrm{diHex})\right)$ contained no $\mathrm{Br}$ ( $c f$. experimental), the polymer is considered to be Ni-terminated, and the -polymer-Ni- terminal unit is considered to be converted into the $\mathrm{H}-$ terminated groups during the work-up including treatment with $\mathrm{HCl}$, similar to poly(anthraquinone)s and poly(pyridine-2,5-diyl). ${ }^{4,9}$ The area of the signal assigned to the terminal- $\mathrm{H}$ and observed at $\delta 7.33$ agrees with the $M_{\mathrm{n}}$ value or degree of polymerization of about 9 estimated from GPC analysis. Although the degree of polymerization is not large, optical and electrochemical data reveal basic properties of the polymer. 


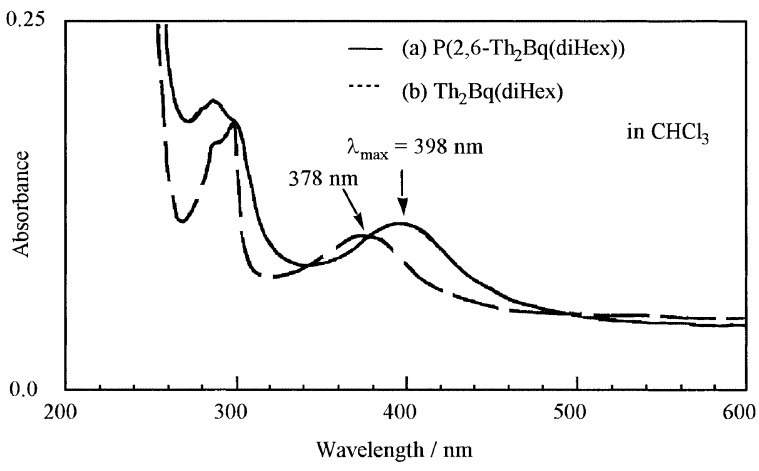

Figure 2. UV-vis spectra of (a) $\mathrm{P}\left(2,6-\mathrm{Th}_{2} \mathrm{~Bq}(\mathrm{diHex})\right)$ and (b) $\mathrm{Th}_{2} \mathrm{~Bq}(\mathrm{diHex})$ in $\mathrm{CHCl}_{3}$.

\section{Optical Properties}

Figure 2 shows UV-vis spectra of $\mathrm{P}\left(2,6-\mathrm{Th}_{2} \mathrm{~Bq}\right.$ (diHex)) and its monomeric compound, $\mathrm{Th}_{2} \mathrm{~Bq}(\mathrm{diHex})$, in chloroform. $\mathrm{P}\left(2,6-\mathrm{Th}_{2} \mathrm{~Bq}(\mathrm{diHex})\right)$ exhibits an $\pi-$ $\pi^{*}$ absorption peak $\left(\varepsilon=9500 \mathrm{M}^{-1} \mathrm{~cm}^{-1}\right.$; molarity is base on the monomeric unit) at $398 \mathrm{~nm}$ (Figure 2 (a)). The peak position of $\mathrm{P}\left(2,6-\mathrm{Th}_{2} \mathrm{~Bq}(\mathrm{diHex})\right)$ is shifted to a longer wavelength by $20 \mathrm{~nm}$ from that of the monomeric compound (Figure 2(b)). P(2,6$\left.\mathrm{Th}_{2} \mathrm{~Bq}(\mathrm{diOct})\right)$ and $\mathrm{P}\left(2,6-\mathrm{Th}_{2} \mathrm{~Bq}(\mathrm{diDod})\right)$ gave the $\pi-$ $\pi^{*}$ absorption peaks at 396 and $393 \mathrm{~nm}$, respectively, in chloroform.

$\mathrm{P}\left(1,3-\mathrm{Th}_{2} \mathrm{~Bq}\right)$ showed a $\pi-\pi^{*}$ absorption peak $(\varepsilon=$ $8000 \mathrm{M}^{-1} \mathrm{~cm}^{-1}$ ) at $344 \mathrm{~nm}$ in NMP and its film cast from NMP gave broadened absorption peak at about $430 \mathrm{~nm}$. In the film, the polymer may take a stacked structure which leads to face-to-face $\pi-\pi$ interaction between the polymer chains, and this may be the origin of the red shift in the solid.

\section{Electrochemical Properties}

All the polymers were susceptible to electrochemical reduction. Table II summarized CV (cyclic voltammetry) data of the polymers. Figure 3 exhibits $\mathrm{CV}$ charts of $\mathrm{P}\left(2,6-\mathrm{Th}_{2} \mathrm{~Bq}(\mathrm{diHex})\right)$ film laid on a Pt plate and of $\mathrm{Th}_{2} \mathrm{~Bq}(\mathrm{diHex})$ in a solution.

Quinone or polyquinone usually receives two-step electrochemical reductions, so-called Wurster type reductions from quinone to radical anion and from radical anion to dianion, respectively. As shown in Figure 3 (b), the monomeric compound $\mathrm{Th}_{2} \mathrm{~Bq}$ (diHex) also received two reductions and the electrochemical reduction is reasonably accounted for by the Wurster type reductions ${ }^{12}$ as shown in Scheme 4.

$\mathrm{P}\left(2,6-\mathrm{Th}_{2} \mathrm{~Bq}(\mathrm{diHex})\right)$ received the corresponding first and second reductions with $E_{\mathrm{pc}}$ of -1.14 and $-1.84 \mathrm{~V}$ vs. $\mathrm{Ag}^{+} / \mathrm{Ag}$, and the electrochemical reduction is accompanied by the color changes as shown in Figure 3 (a).

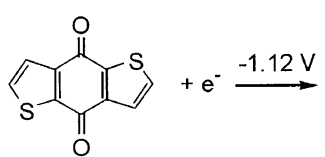<smiles>[O-]c1c2ccccc2c(O)c2sccc12</smiles>

Scheme 4.

Table II. Peak reduction potentials of polymers ${ }^{\mathrm{a}}$

\begin{tabular}{cccc}
\hline run & Compound & $E_{\mathrm{pc}}{ }^{1}$ & $E_{\mathrm{pc}}{ }^{2}$ \\
\hline 1 & $\mathrm{Th}_{2} \mathrm{~Bq}$ & -1.05 & -1.84 \\
2 & $\mathrm{Th}_{2} \mathrm{~Bq}(\mathrm{diHex})$ & -1.12 & -2.10 \\
3 & $\mathrm{P}\left(2,6-\mathrm{Th}_{2} \mathrm{~Bq}(\mathrm{diHex})\right)$ & -1.14 & -1.84 \\
4 & $\mathrm{P}\left(2,6-\mathrm{Th}_{2} \mathrm{~Bq}(\right.$ diOct $\left.)\right)$ & -1.18 & -1.84 \\
5 & $\mathrm{P}\left(2,6-\mathrm{Th}_{2} \mathrm{~Bq}(\mathrm{diDod})\right)$ & -1.15 & -1.85 \\
6 & $\mathrm{P}\left(1,3-\mathrm{Th}_{2} \mathrm{~Bq}\right)$ & -1.50 & -1.74 \\
\hline
\end{tabular}

${ }^{\mathrm{a}} E / V$ vs. $\mathrm{Ag}^{+} / \mathrm{Ag}$. Obtained with polymer film in an $\mathrm{CH}_{3} \mathrm{CN}$ solution of $0.10 \mathrm{M}\left[\mathrm{Bu}_{4} \mathrm{~N}\right] \mathrm{PF}_{6}$.

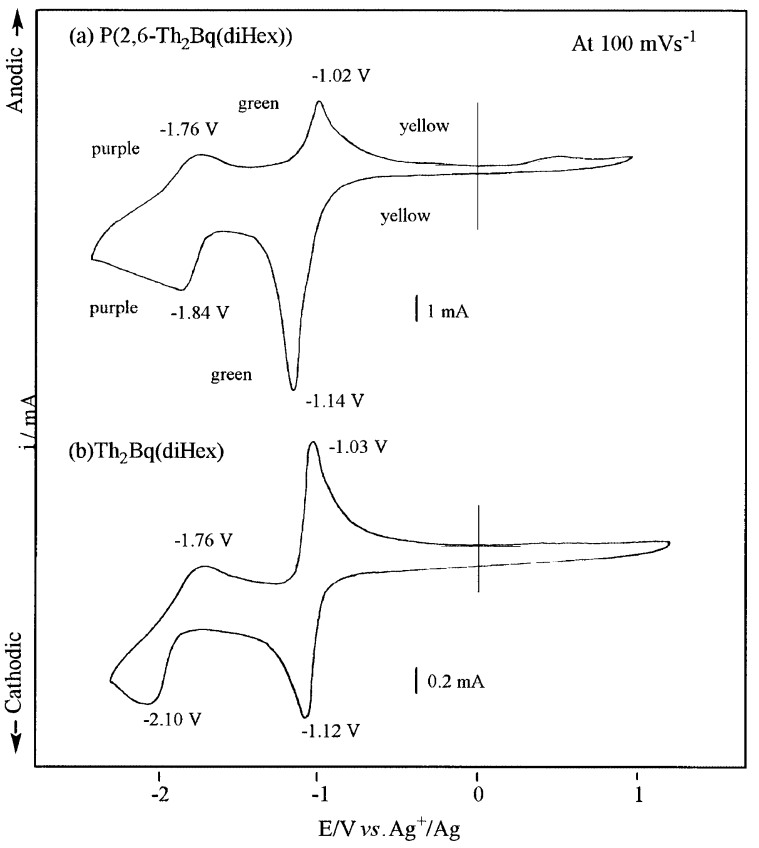

Figure 3. (a) Cyclic voltammogram of $\mathrm{P}\left(2,6-\mathrm{Th}_{2} \mathrm{~Bq}(\mathrm{diHex})\right)$ film cast on a Pt plate in an $\mathrm{CH}_{3} \mathrm{CN}$ solution of $\left[\mathrm{Bu}_{4} \mathrm{~N}\right] \mathrm{PF}_{6}(0.10 \mathrm{M})$ and (b) Cyclic voltammogram of $8.0 \times 10^{-4} \mathrm{M}$ of $\mathrm{Th}_{2} \mathrm{~Bq}(\mathrm{diHex})$ in an $\mathrm{CH}_{3} \mathrm{CN}$ solution of $\left[\mathrm{Bu}_{4} \mathrm{~N}\right] \mathrm{PF}_{6}(0.10 \mathrm{M})$. At $100 \mathrm{mVs}^{-1}$.

The first-step electrochemical reduction or $n$-doping of $\mathrm{P}\left(2,6-\mathrm{Th}_{2} \mathrm{~Bq}(\mathrm{diHex})\right)$ proceeds at a higher potential by about $0.2 \mathrm{~V}$ than that of poly(anthraquinone-1,4diyl)s $\left(E_{\mathrm{pc}}{ }^{1}=-1.38 \mathrm{~V} v s . \mathrm{Ag}^{+} / \mathrm{Ag}\right){ }^{4 a}$ This more facile electrochemical reduction of $\mathrm{P}\left(2,6-\mathrm{Th}_{2} \mathrm{~Bq}(\mathrm{diHex})\right)$ is considered to be a reflection of higher first reduction potential of the monomeric model compound $\left(\mathrm{Th}_{2} \mathrm{~Bq}(\mathrm{diHex}): E_{\mathrm{pc}}=-1.12 \mathrm{~V} v s . \mathrm{Ag}^{+} / \mathrm{Ag}\right)$ than that of anthraquinone $\left(E_{\mathrm{pc}}=-1.30 \mathrm{~V}\right)$ by about $0.2 \mathrm{~V}$. The electrochemically reduced polymer film became partly soluble in $\mathrm{CH}_{3} \mathrm{CN}$, and the smaller anodic $n$ dedoping peak at $-1.02 \mathrm{~V}$ than cathodic n-doping peak at $-1.14 \mathrm{~V}$ was attributed to loss of the polymer due to partially dissolution of the reduced polymer in the solu- 


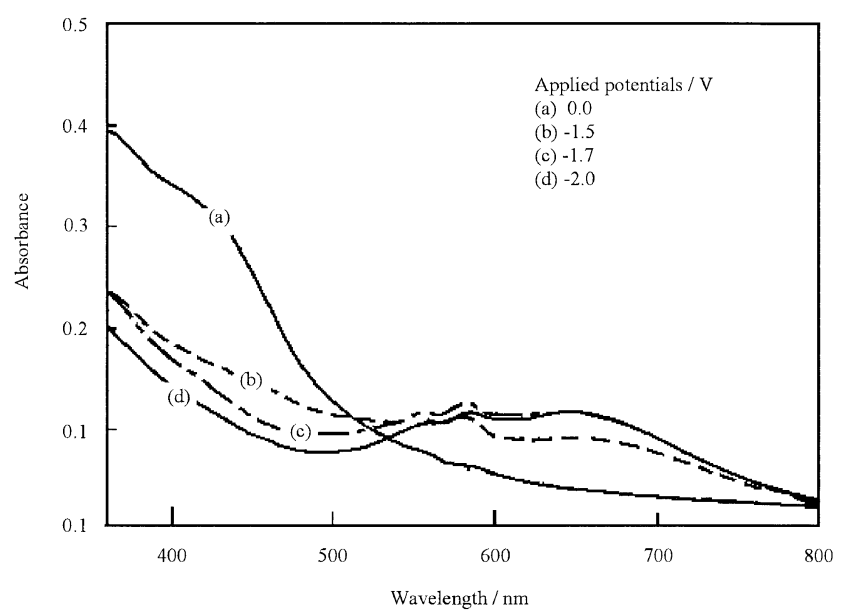

Figure 4. Electrochromism of a film of $\mathrm{P}\left(1,3-\mathrm{Th}_{2} \mathrm{~Bq}\right)$ on an ITO glass electrode at various applied potentials $v s . \mathrm{Ag}^{+} / \mathrm{Ag}$. The curve (a) shows UV-vis spectrum of the as-cast film of $\mathrm{P}(1,3-$ $\mathrm{Th}_{2} \mathrm{~Bq}$ ). Applied potential: (b) -1.50 , (c) -1.70 , (d) $-2.0 \mathrm{~V} v s$. $\mathrm{Ag}^{+} / \mathrm{Ag}$.

tion. Without the chemical reduction, the film of $\mathrm{P}(2,6-$ $\mathrm{Th}_{2} \mathrm{~Bq}($ diHex $)$ ) was stable in $\mathrm{CH}_{3} \mathrm{CN}$ and dissolution into $\mathrm{CH}_{3} \mathrm{CN}$ was not observed. However, coloring of the solution due to dissolution of the $n$-doped $\mathrm{P}(2,6-$ $\mathrm{Th}_{2} \mathrm{~Bq}(\mathrm{diHex})$ ) was observed after the electrochemical reduction. Because of loss of $\mathrm{P}\left(2,6-\mathrm{Th}_{2} \mathrm{~Bq}(\mathrm{diHex})\right)$ by dissolution, repeated scanning gave smaller $\mathrm{CV}$ peaks.

$\mathrm{P}\left(1,3-\mathrm{Th}_{2} \mathrm{~Bq}\right)$ showed similar two-step reduction. The CV curve of the polymer gives electrochemical reduction peaks, $E_{\mathrm{pc}}$, at about $-1.50 \mathrm{~V}$ and $-1.74 \mathrm{~V} v s$. $\mathrm{Ag}^{+} / \mathrm{Ag}$, respectively. The polymer film was stable at the stage of the first reduction. However, after the second step reduction, the polymer was dissolved in the solution. The doping level of the polymer (stored negative charge/repeating unit) was estimated at 1.6 from the doping current obtained at the first $\mathrm{CV}$ cycle carried out beyond the second reduction. The first reduction was coupled with $n$-dedoping peak at $-1.30 \mathrm{~V}$. The second reduction did not show the $n$-dedoping due to the dissolution of the polymer. Reduction of the benzoquinone unit will give an anion radical of the benzoquinone unit and dianion of a hydroquinone unit. ${ }^{4 \mathrm{~d}, 8 \mathrm{a}, 13}$ Formation of such reduced species will generate sulfur with a high valency for $\mathrm{P}\left(1,3-\mathrm{Th}_{2} \mathrm{~Bq}\right){ }^{13}$ This will make the reduced state unstable and may be the reason for the irreversibility of the electrochemical process. The dopant, $\mathrm{Bu}_{4} \mathrm{~N}^{+}$, may have a strong affinity toward the $n$-doped polymer, possibly by coordination to $\mathrm{S}$, and, if this is the case for $\mathrm{P}\left(1,3-\mathrm{Th}_{2} \mathrm{~Bq}\right)$, it also accounts for the irreversibility, at least partly. The polymer showed electrochromism from brown to blue with electrochemically doping, and Figure 4 exhibits changes of UV-vis spectrum of the film of $\mathrm{P}\left(1,3-\mathrm{Th}_{2} \mathrm{~Bq}\right)$ during electrochemical reduction. As describe above, the film of neu-

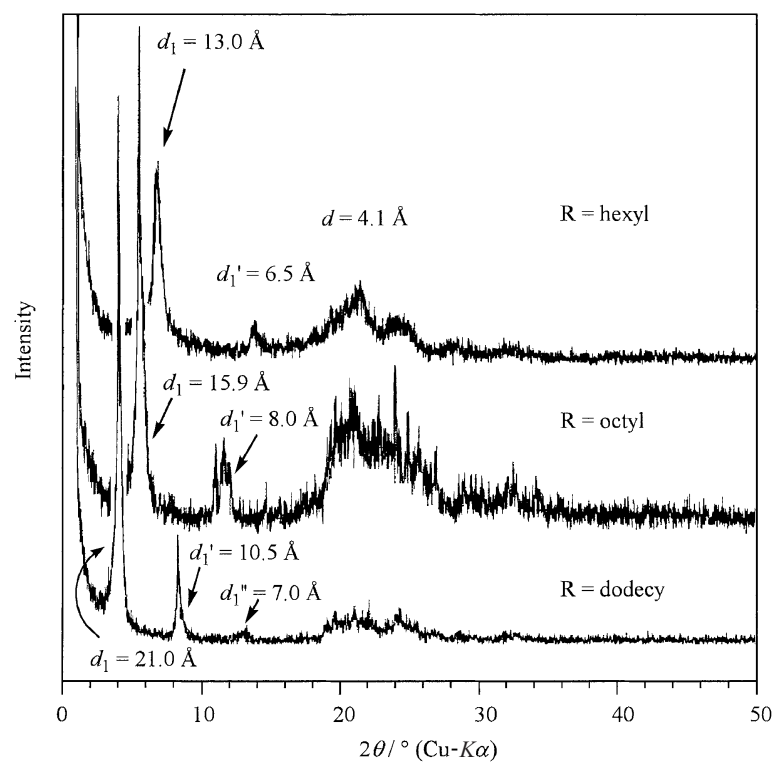

Figure 5. $\mathrm{X}$-Ray diffraction patterns of $\mathrm{P}\left(2,6-\mathrm{Th}_{2} \mathrm{~Bq}(\mathrm{diR})\right)$.

tral $\mathrm{P}\left(1,3-\mathrm{Th}_{2} \mathrm{~Bq}\right)$ gave a broad peak at $430 \mathrm{~nm}$ at $0.0 \mathrm{~V}$ vs. $\mathrm{Ag}^{+} / \mathrm{Ag}$. On application of the reduction potential, at $-1.50 \mathrm{~V}$, the polymer film showed decrease of the $\pi-\pi^{*}$ absorption peak at $430 \mathrm{~nm}$, and new absorption band(s) appeared in a longer wavelength $(500-800 \mathrm{~nm})$ region. By applying higher reduction potentials of -1.7 and $-2.0 \mathrm{~V}$, intensity of the new absorption band(s) increased.

\section{Packing Structure}

Figure 5 depicts powder XRD patterns of $\mathrm{P}(2,6-$ $\left.\mathrm{Th}_{2} \mathrm{~Bq}(\mathrm{diR})\right)$. The XRD patterns show a sharp peak in a low angle region $\left(2 \theta(\mathrm{Cu}-K \alpha)<7^{\circ}\right)$, similar to XRD patterns of previously reported regioregular head-to-tail poly(3-alkylthiophene-2,5-diyl) HT-P3RT and head-tohead poly $\left(4,4^{\prime}\right.$-dialkyl-2,2' -bithiazole-5, $5^{\prime}$-diyl) HHP4RBTz. ${ }^{14}$ Main-chain-type poly(heterocycle)s with long alkyl side chains often give similar XRD peaks in the low angle region, and its corresponding $d_{1}$ value has been assigned to a distance between the poly(heterocycle) main chains separated by the alkyl side chains. ${ }^{9}, 14$

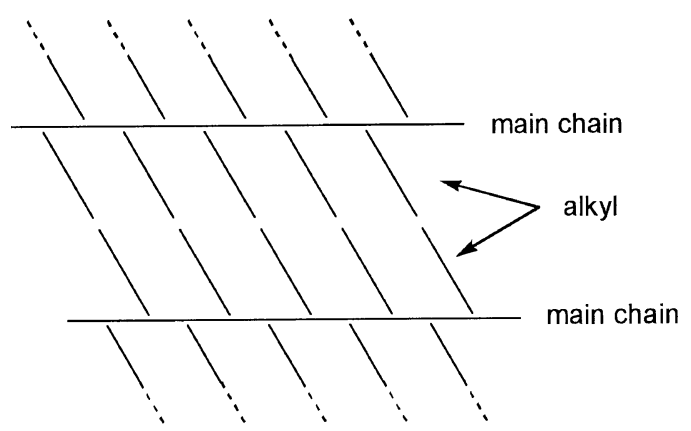

Scheme 5. An end-to-end packing model of $\pi$-conjugated polymers with long side chains. 


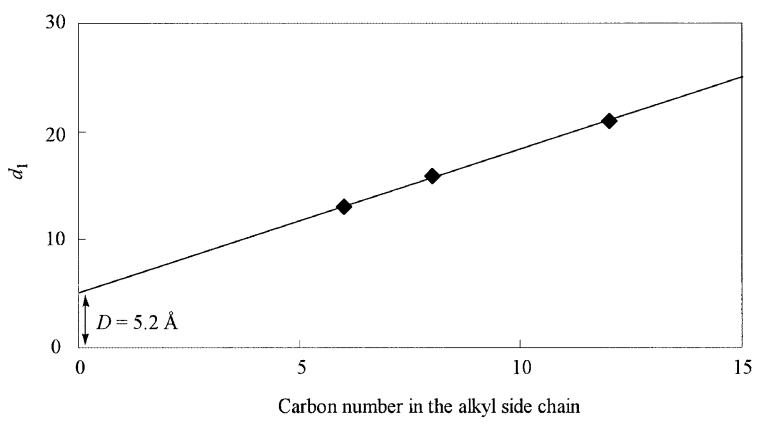

Figure 6. Relationship of $d_{1}$-space and carbon number of alkyl side chain of $\mathrm{P}\left(2,6-\mathrm{Th}_{2} \mathrm{~Bq}(\mathrm{diR})\right)$.

The $d_{1}$-value given in Figure 5 increases with the length of the side alkyl chain, and plots of the $d_{1}$-value $v s$. number of the carbon of alkyl side chain gives a linear line with a slope of $1.33 \AA$ per number of carbon, as shown in Figure 6. The slope of the linear line is smaller than those (1.8-2.0 $\AA$ /carbon) observed with HT-P3RT and P4BTz, however, it is still larger than the unit height of alkyl chain (the $-\mathrm{CH}_{2}-\mathrm{CH}_{2}-$ distance). ${ }^{14 \mathrm{~d}, 15}$ These data suggests that the polymer take an ordered structure with an end-to-end type packing shown above (Scheme 5) rather than an interdigitation packing. The density of the alkyl chain (1 alkyl chain per about $8 \AA$ of the repeating quinone unit) along the polymer chain is smaller than that ( 1 alkyl per about $4 \AA$ ) of HT-P3RT. Therefore, the alkyl side chain is considered to take a less stiff structure in the side space of the polymer main chain. This seems to account for the smaller slope of the straight line given in Figure 6 than those observed with HT-P3RT and HH-P4RBTz. The XRD pattern also exhibits 2 nd $\left(d_{1}{ }^{\prime}=d_{1} / 2\right)$ and 3rd $\left(d_{1}{ }^{\prime \prime}=d_{1} / 3\right)$ peaks of the $d_{1}$ peak.

The peak at about $2 \theta=21.5^{\circ}(d=4.1 \AA)$ in Figure 5 is characteristic of polymers with long alkyl chains and usually assigned to packing distance between alkyl chains ${ }^{14}$ although in the present case it may contain a contribution from face-to-face packing of the polymer planes. $\mathrm{P}\left(2,6-\mathrm{Th}_{2} \mathrm{~Bq}(\mathrm{diHex})\right)$ gave a density of $1.41 \mathrm{~g} \mathrm{~cm}^{-3}$. If one assumes a layered packed structure of the polymer with an interlayer distance of about $4 \AA$ which is normal for stacked $\pi$-conjugated polymers, ${ }^{13}$ and the repeating height of $8.0 \AA$, this assumption and the $d_{1}$-value of $13 \AA$ give a calculated density of $\left(386 / 6 \times 10^{23}\right) /\left(4 \times 8 \times 13.0 \times 10^{-24}\right)=1.55 \mathrm{~g} \mathrm{~cm}^{-3}$. Polymers usually give a lower observed density than a calculated density because of their containing amorphous parts, and the observed density with $\mathrm{P}(2,6-$ $\left.\mathrm{Th}_{2} \mathrm{~Bq}(\mathrm{diHex})\right)$ is reasonable for the calculated density. $\mathrm{P}\left(2,6-\mathrm{Th}_{2} \mathrm{~Bq}(\mathrm{diOct})\right)$ and $\mathrm{P}\left(2,6-\mathrm{Th}_{2} \mathrm{~Bq}\right.$ (diDod)) also showed density (1.36 and 1.28, respectively), which is reasonable for their calculated values (1.41 and 1.34 , respectively). The intercept $\mathrm{D}(5.2 \AA)$ of the

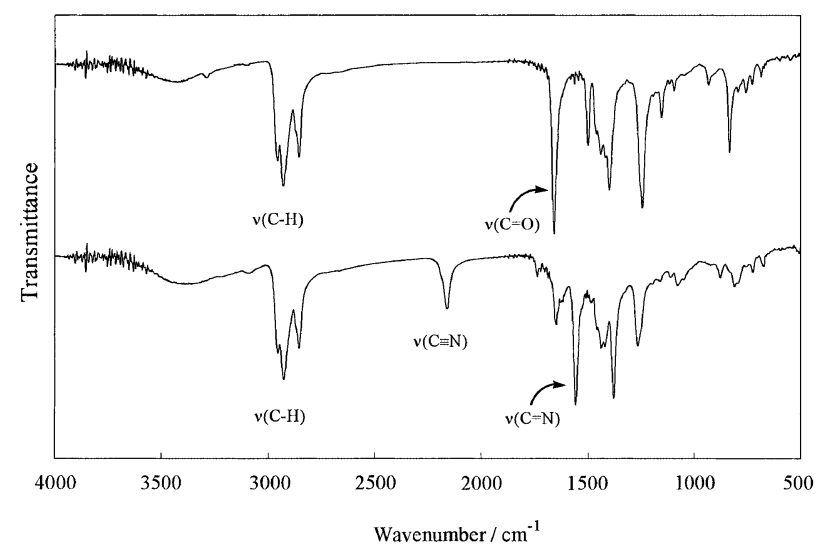

Figure 7. IR spectra of (a) $\mathrm{P}\left(2,6-\mathrm{Th}_{2} \mathrm{~Bq}(\mathrm{diHex})\right)$ and (b) $\mathrm{P}($ thiophene-fused DCNQI-2,6-diyl).

linear line in Figure 6 is considered to correspond to the thickness of the main chain.

\section{Chemical Transformation}

Dicyanoquinonediimine (DCNQI) and its derivatives are typical electron acceptors stronger than quinones and many studies have been carried out with these compounds. ${ }^{6,10}$ On this basis, we have carried out transformation reaction of the fused dithiophenebenzoquinone unit of $\mathrm{P}\left(2,6-\mathrm{Th}_{2} \mathrm{~Bq}(\mathrm{diHex})\right)$ into the DCNQI unit by using bis(trimethysilylcarbodiimide), (TMS$\mathrm{N}=\mathrm{C}=\mathrm{N}-\mathrm{TMS}$ ) in the presence of the $\mathrm{TiCl}_{4}$ (Scheme 5). Data from elemental analysis of the obtained black powder indicated that the quinone group of $\mathrm{P}(2,6-$ $\mathrm{Th}_{2} \mathrm{~Bq}(\mathrm{diHex})$ ) was transformed into the DCNQI unit in about $90 \%$ degree. IR spectrum of the obtained polymer showed new absorption bands of $v(\mathrm{C} \equiv \mathrm{N})$ at $2156 \mathrm{~cm}^{-1}$ and of $v(\mathrm{C}=\mathrm{N})$ at $1555 \mathrm{~cm}^{-1}$, as exhibited in Figure 7. However, the peak of $v(\mathrm{C}=\mathrm{O})$ at about $1650 \mathrm{~cm}^{-1}$ still remained. The obtained polymer was soluble in chloroform and toluene.
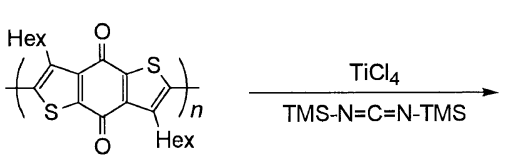$$
\mathrm{P} \text { (thioph }
$$

Scheme 6. Transformation to a DCNQI polymer.

The UV-vis spectrum of the obtained polymer, P(thiophene-fused DCNQI-2,6-diyl), showed absorption peak at about $440-470 \mathrm{~nm}$ in chloroform, which was shifted by about $70 \mathrm{~nm}$ to a longer wavelength compared with that of $\mathrm{P}\left(2,6-\mathrm{Th}_{2} \mathrm{~Bq}(\mathrm{diHex})\right)$.

As shown in Figure 8, the CV chart of a cast film of $\mathrm{P}$ (thiophene-fused DCNQI-2,6-diyl) laid on a $\mathrm{Pt}$ plate shows two reduction peaks with $E_{\mathrm{pc}}{ }^{1}$ and $E_{\mathrm{pc}}{ }^{2}$ of $-0.56 \mathrm{~V}$ and $-1.06 \mathrm{~V} v s$. $\mathrm{Ag}^{+} / \mathrm{Ag}$, respectively. The first reduction peak locates near that (about $-0.5 \mathrm{~V} v s$. 


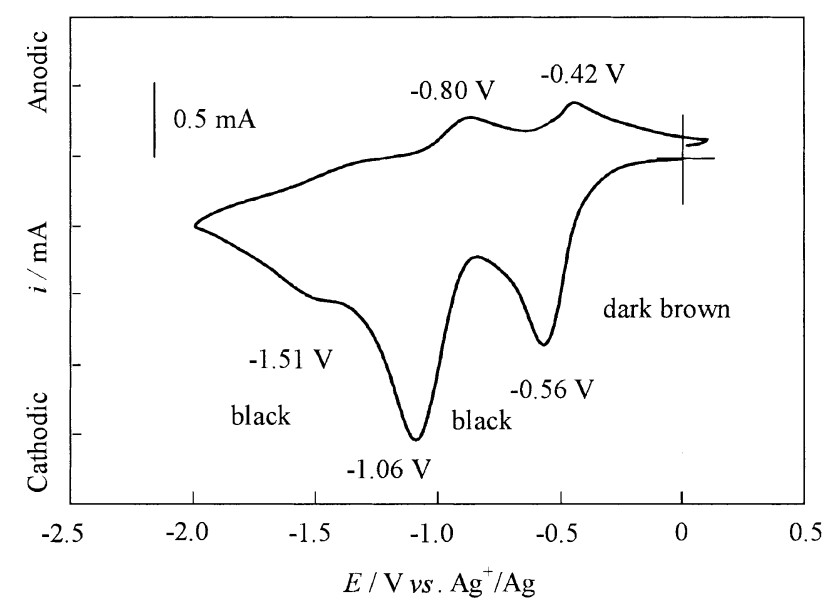

Figure 8. $\mathrm{CV}$ chart of a film of $\mathrm{P}$ (thiophene-fused DCNQI-2,6diyl) on a Pt plate in an $\mathrm{CH}_{3} \mathrm{CN}$ solution of $\left[\mathrm{Bu}_{4} \mathrm{~N}\right] \mathrm{PF}_{6}(0.10 \mathrm{M})$ at $100 \mathrm{mVs}^{-1}$.

$\left.\mathrm{Ag}^{+} / \mathrm{Ag}\right)$ of poly ( $p$-benzoquinone). ${ }^{4 \mathrm{~d}}$ The small peak at negative higher potential, (the peak at about $E_{\mathrm{pc}}{ }^{3}$ value of $-1.51 \mathrm{~V} v s$. $\mathrm{Ag}^{+} / \mathrm{Ag}$ ) may originate from the remaining quinone unit. According to the reduction, color of the film changed to black from dark brown. By the electrochemically reduction, the polymer film became partly soluble in the $\mathrm{CV}$ solvent $\left(\mathrm{CH}_{3} \mathrm{CN}\right)$, and the smaller $n$-dedoping peaks at -0.42 and $-0.80 \mathrm{~V}$ were attributed to loss of electrochemically reduced polymer into the solvent.

\section{CONCLUSION}

New main chain type polyquinones constituted of 4,8-dihydrobenzodithiophene-4,8-dione rings have been prepared. UV-vis spectrum of the polymers gave $\pi-\pi^{*}$ absorption at a longer wavelength than that of the corresponding monomers. The polymers showed two electrochemical reduction peaks and exhibited elctrochromism. Transformation to DCNQI unit of $\mathrm{P}\left(2,6-\mathrm{Th}_{2} \mathrm{~Bq}\right.$ (diHex)) was achieved and the obtained polymer received more facile reduction than the precursor polyquinone. These polymers are expected to serve as n-type conducting materials in electronic and optical devices.

\section{REFERENCES}

1. a) "Handbook of Organic Conductive Molecules and Polymers", H. S. Nalwa, Ed., John Wiley \& Sons Ltd., Chichester, 1997, vol. 2.

b) W. R. Salaneck, D. T. Clark, and E. J. Samuelsen, "Science and Application of Conducting Polymers", Adam Hilger, Bristol, 1991.

2. a) A. O. Pati, D. Y. Curtin, and I. C. Paul, J. Am. Chem. Soc., 106, 348 (1984).

b) A. O. Pati, D. Y. Curtin, and I. C. Paul, J. Am. Chem. Soc.,
106, 4010 (1984).

c) K. E. O'Shea, M. A. Fox, J. Am. Chem. Soc., 113, 611 (1991).

d) V. Goule, A. Harriman, and J.-M. Lehn, J. Chem. Soc., Chem. Commun., 1034 (1993).

e) D. G. Johnson, M. P. Niemczyk, D. W. Minsek, G. P. Wiederrecht, W. A. Svec, G. L., III Gaines, and M. R. Wasielewski, J. Am. Chem. Soc., 115, 4618 (1993).

f) J. L. Sessler, V. L. Capuano, and A. Harriman, J. Am. Chem. Soc., 115, 4618 (1993).

g) T. Hayashi, T. Miyahara, N. Hashizume, and H. Ogoshi, J. Am. Chem. Soc., 115, 2049 (1993).

h) K. Yamamoto, T. Asada, H. Nishide, and E. Tsuchida, Bull. Chem. Soc. Jpn., 63, 1211 (1990).

3. a) A. S. Lindsey, M. E. Peover, and N. G. Savill, J. Chem. Soc., 4558 (1962).

b) G. Arai, T. Sugaya, M. Sakamoto, and Y. Yasumori, Bull. Chem. Soc. Jpn., 65, 594 (1992).

c) A. B. Kon, J. S. Foos, and T. L. Rose, Chem. Mater, 4, 416 (1990).

d) J. Grimshaw and S. D. Perera, J. Electroanal. Chem., 278, 287 (1990).

e) P. M. Hoang, S. Holdcroft, and B. L. Funt, J. Electrochem. Soc., 132, 2129 (1985).

f) P. Wan, B. D. Martin, S. Parida, G. Rethwisch, and J. D. Dordick, J. Am. Chem. Soc., 117, 12885 (1995).

4. a) T. Yamamoto and H. Etori, Macromolecules, 28, 3371 (1995).

b) H. Etori, T. Kanbara, and T. Yamamoto, Chem. Lett., 461 (1994).

c) Y. Muramatsu and T. Yamamoto, Chem. Lett., 581 (1997).

d) T. Yamamoto, T. Kimura, and K. Shiraishi, Macromolecules, 32, 8886 (1999).

e) Y. Muramatsu and T. Yamamoto, Denki Kagaku, 66, 223 (1998).

f) T. Yamamoto and K. Shiraishi, Chem. Lett., 895 (1998).

5. G. Power, P. Hodge, I. Clarke, I. D. Robjohns, M. A. Robjohns, and I. Goodbody, Chem. Commun., 873 (1998).

6. a) A. Aumüller, P. Erk, G. Klebe, S. Hunig, J-U. von Schuntz, and H-P. Werner, Angew. Chem. Int. Ed. Eng., 25, 740 (1986). b) S. Hünig, J. Mater. Chem., 5, 1409 (1995).

7. D. W. Slocum and P. L. Gierer, J. Org. Chem., 41, 3668 (1976).

8. a) D. W. H. MacDowell and J. C. Wisowaty, J. Org. Chem., 37, 1712 (1972).

b) D. W. H. MacDowell and F. L. Ballas, J. Org. Chem., 39, 2239 (1974).

9. a) T. Yamamoto, Prog. Polym. Sci., 17, 1153 (1992).

b) T. Yamamoto, Macromol. Rapid. Commun., 23, 583 (2002).

10. a) A. Aumüller and S. Hünig, Angew. Chem. Int. Ed. Eng., 23, 447 (1984).

b) K. Takahashi, Y. Mazaki, and K. Kobayashi, Chem. Commun., 2275 (1996).

c) K. Kobayashi, Y. Mazaki, H. Namba, K. Kikuchi, K. Saito, I. Ikemoto, S. Hino and N. Kosugi, J. Mater. Chem., 5, 1625 (1995).

11. T. Yamamoto, T. Kamijoh, and I. Wataru, J. Polym. Sci., Part A: Polym. Chem., 38, 1642 (2000). 
12. S. Huning and P. Erk, Adv. Mater., 3, 225 (1991).

13. K. Kobayashi and C. L. Gajurel, J. Chem. Soc., Chem. Commun. 1779 (1986).

In the $\mathrm{P}\left(1,3-\mathrm{Th}_{2} \mathrm{~Bq}\right)$ system, anion radicals formed in the adjacent two repeating unit may undergo bond rearrangement to form a thiophene $=$ thiophene type quinoide unit in the main chain. In this case, sulfur with the high valency is not generated.

14. a) R. D. McCullough, S. Tristam-Nagle, S. P. Williams, R. D. Lowe, and M. Jayaraman, J. Am. Chem. Soc., 115, 4910 (1993). b) T.-A. Chen, X. Wu, and R. D. Rieke, J. Am. Chem. Soc., 117, 233 (1995).

c) M. J. Winokur, P. Wamsley, J. Moulton, P. Smith, and A. J. Heeger, Macrolecules, 24, 3812 (1991).

d) T. Yamamoto, D. Komarudin, M. Arai, B.-L. Lee, H. Suganuma, N. Asakawa, Y. Inoue, K. Kubota, S. Sasaki, T. Fukuda, and H. Matsuda, J. Am. Chem. Soc., 120, 2047 (1998).

15. H. W. Hsieh, B. Post, and H. Morawetz, J. Polym. Sci., Polym. Phys. Ed., 14, 1241 (1976). 